\title{
A Dynamic Planner as a Sustainable Planning Way: A Bridge between the Law, Technical Knowledge and the Local Population
}

\author{
Fernanda Nascimento Corghi ${ }^{1}$ and Diógenes Cortijo da Costa $^{2}$ \\ 1. Architecture and Urbanism and Applied Arts Department, Federal University of São João del-Rei, São João del-Rei 36307352, \\ Brazil \\ 2. Faculty of Civil Engineering and Architecture and Urbanism, State University of Campinas, Campinas 13083852, Brazil
}

\begin{abstract}
The social and environmental demands in Brazilian cities are usually neglected by the local municipal powers due to a heavy bias toward speculative capital. The main issue is a public administration that benefits the private initiative instead of popular and environmental values and needs. Despite federal efforts at the end of the 20th and beginning of the 21st century, water resources and urban reform policies are not able to ensure a connection between these two issues in the urban environment. Aiming at showing a new approach of citizenship and environmental rights in a developing country, Bauru, a Brazilian city located in the state of São Paulo, was used as a study case. In this scenario, the research is based on the action research method, in which a dynamic profile of the researchers was adopted in order to solidify environmental and social issues in the urban planning process. This article shows the advantages in using the river basin as an urban planning territory in the city master plan, and providing continuous technique support to the citizen, through the role played by the researcher-planner between government and population, as a way to possibly reach social and environmental interests. The territorial perception of the river basin by citizens brings effective environmental and social results.
\end{abstract}

Key words: Urban policy, water policy, river basin, administrative land division, governance, planning, action research.

\section{Introduction}

In the second half of the 19th century, much political effort in Brazil was directed towards enhancing local governance and making specific laws for the ecological and social functions of land use. Since the 1990s, Latin American countries have trended toward democratization and decentralization of government practices [1]. In Brazil, this tendency resulted in higher autonomy for municipalities just after the period when the centralized federal government was ruled by a military government (1964-1985). The cities increased their autonomy after

Corresponding author: Fernanda Nascimento Corghi, Ph.D., architect, urban planner and university teacher, research fields: territorial planning and management (emphasis on watersheds), urban design (emphasis on urban land division project), topography, urban erosion prevention, law of use and occupation of land and sanitation. E-mail: corgho@gmail.com. the 1988 Brazilian Constitution. However, they also inherited numerous negative consequences from the military government: recession, inflation, unemployment and a decline in wage levels, along with an enormous contingent of poor people who moved to urban areas [2].

In 1988, it was possible to achieve democratic and ecological rights with the Brazilian's Constitution through Articles 182, 183 and 225. Articles 182 and 183 are the foundation for urban policies and declare a democratic use of the urban land and property. Article 182 states that municipal governments must follow a master plan to ensure that the land is used for its optimal social function. Article 183 gives the rights of ownership of a piece of land to the inhabitant if one has lived on it for five consecutive years. Article 225 establishes an ecologically balanced environment as a 
right for current and future generations.

Unfortunately, Brazilian politics is marked by the concentration of power among few groups, political coronelism, clientelism, corruption and the deviation of funds [1], which make the application of social and environmental rights difficult. This article shows an effective way to protect social and environmental rights. When urban and environmental politics are understood by citizens, technical knowledge can change the space of inhabitants and users.

A case study in Bauru, a city located in the state of São Paulo, is reported here to illustrate advances in urban planning, since it is a Brazilian city that provides technical support to the local population and turns the micro basin into an administrative area of the master plan as well as turns it into a territory area by its own citizens and planners.

\section{Urban Policies}

In the 21 st century, a law called the City Statute (Law 10.257/2001) was implemented to ensure the rights of Articles 182 and 183 by applying them as a tool for the social use of urban land. These guidelines are difficult to enforce due to urban reform, which includes the restriction of property speculation, reducing socioeconomic inequality and maximizing the planning and management of the city by its own citizens. Every Brazilian territory must produce a participatory master plan up to 2006 and cities above 20,000 inhabitants must participate.

This represents a wide territory as 1,683 Brazilian municipalities are incorporating the master plan in a participatory scheme. The Ministry of Cities was created "for designing and implementing urban policies", and it represents a "chance to increase democratization of urban management..., promoting participatory democracy at a national level" [2].

Despite these federal efforts, not all cities produced a good master plan, but instead, produced a document stating that they would obey the federal law. Many Brazilian cities were prevented from applying social function land tools because land use in their territories is predominantly determined by local powers such as farmers, big corporations and elite interests.

There is a perverse procedure for the implementation of this re-democratization process in the end of the 20th century, when neoliberal policies were adopted [2]. At the same time, there is a strong local power that has been effectively implemented because of federal decentralization. Relaxed economic restrictions have led many cities to focusing on obtaining external capital, taking much of the focus off of the well-being of poor citizens.

The globalized economic system makes it possible to introduce industrial parks at local levels, thus, increasing the competition between cities to attract these big corporations. Furthermore, local natural resources started to be considered a local advantage, becoming intertwined with technological and scientific knowledge, the social habits of local elites, abilities in producing association capital, and influencing networks and strategies in contrast to nation-state policy objectives [3].

The City Statute is a law that focuses on participatory and democratic land use, and improves local management. However, the emergence of land use has its origins in class struggle, even in the 20th century. The monetary crisis and conflicts for territory, as well as specific land use, are the causes of death and violence in major metropolitan Brazilian regions, and are also related to poverty and capital concentration. The regulatory master plan has shown that laws alone in underdeveloped countries are unable to adequately address the issues of undemocratic cities and of exclusion when it comes to land division.

\section{Brazilian Water Policies}

Usually, issues concerning water are connected to urban impacts such as floods, risks of human occupation, depth erosion, pollution, potable water shortage and urban disasters. In some cases, issues 
with water and the river basin are ecological and social problems that must be addressed with the preliminary intention of foreseeing future impacts and allowing urban planning.

In Brazil, efforts to relate the river basin with human activities have been carried out with Conama (National Council of Environment)'s Resolution (Law 001/1986). This resolution requires an EIA (environmental impact assessment) in the river basin when a future enterprise is to be implemented. At the same time, public opinion must be consulted during the proposal of a project, program, plan or policies [4].

The Brazilian River Resources Policy (Law 9.433/97) defines river basins as planning territories and addresses the management of the river resources in Brazil. Brazil has 13 basins in total, which makes political decentralization a general principle. Moreover, the participation of public power, users and communities must occur through river basin committees. Ceará's historic water committees have advantages in terms of participation [5], but when it comes to water resource management, participation can only be achieved when it "is framed by an analytical framework".

These river basin committees can choose the basin scale: a total river basin, a tributary sub-basin of a principal river or an affluent of a tributary river and a group of basins and sub-basins in sequence.

The issue of the boundary and scale arises when working with a little river basin or a river basin of zero degree. The adoption of these land boundaries increases the possibility of local information being included, monitored and supervised by the local population. Therefore, the micro river basin can be defined by the study area of the planning land, including monitoring done by users and inhabitants, and these results can be extrapolated to other micro river basins [6].

The river basin can be used as a prevention impact area, especially if the master plan is integrated with the drainage master plan. However, the basin does not need to be addressed in the master plan, nor does its hydrological behavior need to be known for working with an urbanization process.

Settlements with less than 100 ha do not need EIA evaluation according to Conama Resolution 001/86. Yet they need an environmental license, which can be acquired by the environmental department of the city (Conama Resolution (237/1997)). For a set of small settlements occurred in a consecutive period of time, the impact is computed in the specific basin in which they are located.

The master plan has a lack of knowledge and guidance [7] for addressing aspects of environmental preservation space without sufficient warnings pointing devices to prevent the occupation of areas at risk of flooding (Fig. 1).

Furthermore, if efforts are already taken to turn the basin into a management territory by subsidizing political activity related to other spheres of government, such as the master plan, more effort must be done to turn the micro river basin into a management territory. UN (United Nations) suggested a scenario called an "adaptive mosaic", to which the users of the river basin must be connected and integrated to reach a sustainable government [8].

In the Galisteo Basin in Mexico, there is a conservation program, whereby residents take active part "in the land's long-term stewardship and restoration", enjoying and protecting the land while forging a community network [9]. In the Harlem River

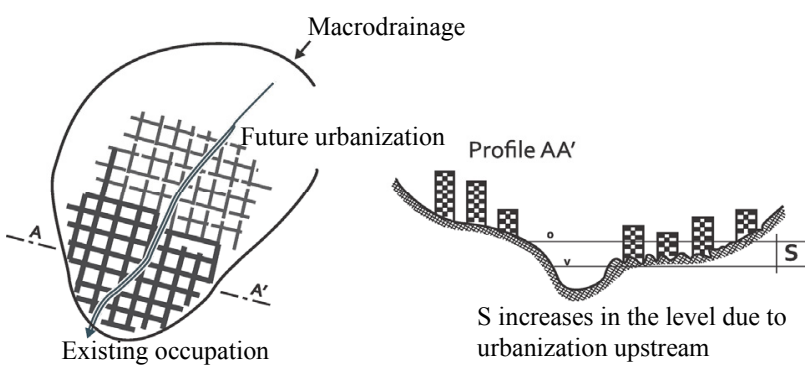
(a)

(b)

Fig. 1 Occupation in hydrographic basin: (a) watersheds direction from downstream to upstream; (b) occupation in lowland areas. 
in South Bronx, the local population started a movement to clear and use the river. One of the aims of the South Bronx Alliance is to maximize the feeling that the river belongs to the entire community $[10]$.

\section{City Master Plan by Micro Basin Division Example}

The case study in this article is a Brazilian city called Bauru. Bauru is located at the center of the State of São Paulo (Fig. 2) and it is in a natural

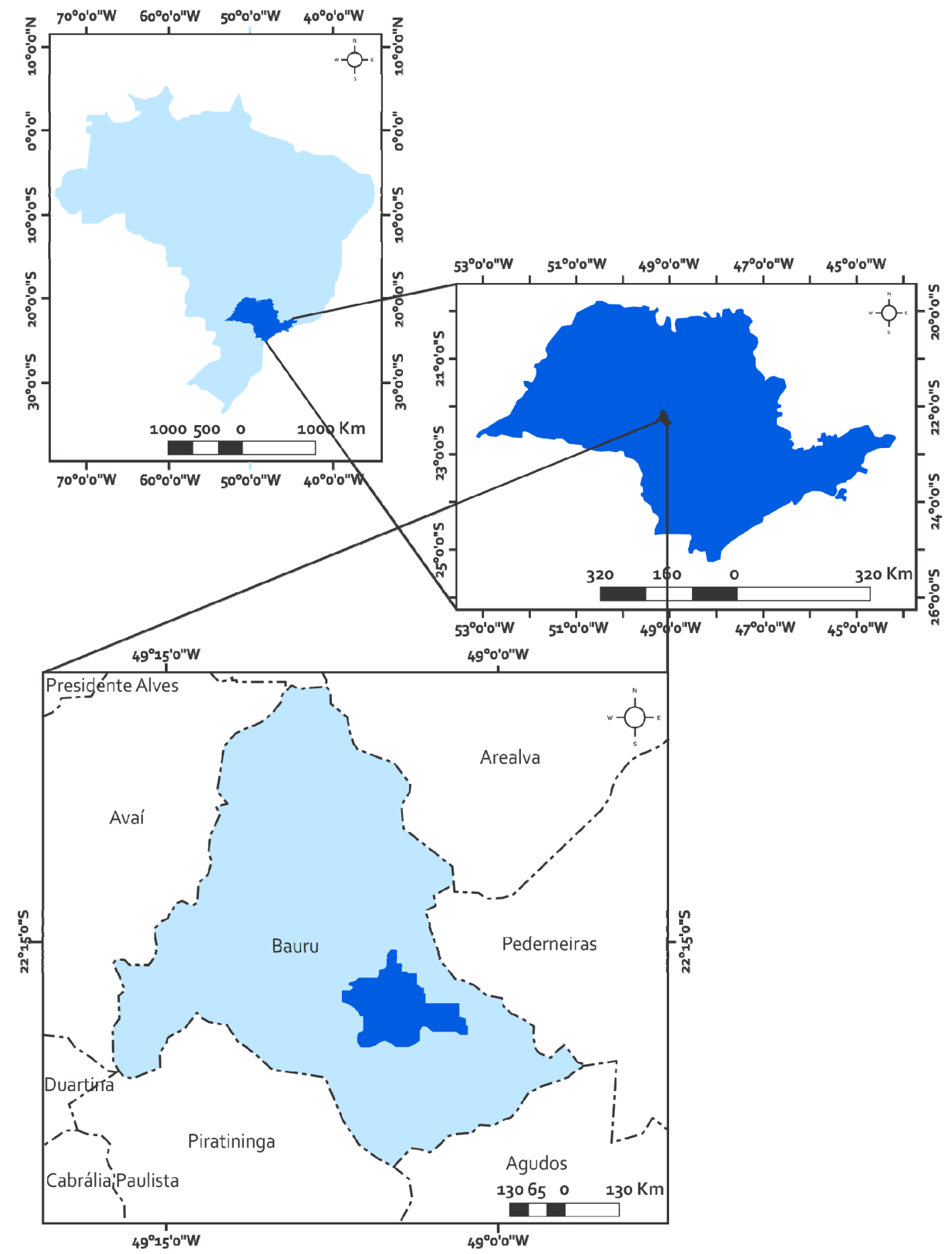

Fig. 2 Bauru City in the State of São Paulo, Brazil. 
amphitheater approximately $5 \mathrm{~km}$ in radius, modeled by several streams at the headwaters of the Bauru River. The regional relief presents wide and gentle hills, and the rocks are sandstones of the Marília and Adamantina Formations, besides Cenozoic Formations.

The city presents a subtropical climate. From 1991 to 1995 , the average maximum temperature was $29.1^{\circ} \mathrm{C}$ and the average minimum temperature was $16.6^{\circ} \mathrm{C}$. The typical soil in Bauru is residual from the sandstone of Marília, Adamantina and Cenozoic Formations, forming a texture of sand with a little clay. The soil formation in a tropical climate, marked by the alternation of rainy seasons and droughts, intensifies the leaching of the thin surface horizon, producing a porous and permeable structure, usually with a deep groundwater table. Aside from high erodibility, soils are also collapsible [11].

Bauru has suffered from urban erosion since the increase of urbanization started with a population shift toward Brazil's center. There were many landowners at that time who support the activities of the colonists. Cities were formed along rivers and streams, included Bauru, which was founded in the end of the 19th century. Its soil was carved with trails and streets, increasing erosion.

In the 20th century, Bauru increased the number of informal settlements and habitation buildings, and consequently urban erosion increased. Part of this process increased between the military (1960s-1980s) and neoliberal (1990s-today) economic-politic periods. There is a clear complicity between public power and capital interest, even in municipal power, in occupied slopes and river margins with unqualified settlements [12].

During the military government, in Bauru, 30 habitation buildings were constructed, causing almost 50 cases of urban erosion [13]. Especially in the 1990s and 2000s, informal settlements increased 400\%, consisting mainly of those excluded from the housing system. In those two decades, the number of poor people living in informal areas increased from 2,000 to nearly 13,000 in Bauru. After the ratification of the Brazilian Constitution, the city contracted an external loan for the first time. These are some of the neoliberal consequences [14].

\subsection{Bauru Participative Master Plan Process}

When it comes to incorporate the master plan in real life, Bauru has the same problem as most of Brazilian cities. The decentralization management related with the water resources governance (National Policy of River Resources_-Law 9.433/97) and urban policies (City Statute-Law 10.257/01) made Bauru city planners adopt an urban subdivision in 12 micro basins, as to implement and distribute the participatory master plan from 2005 to 2008 (Fig. 3).

All 12 micro basins are located in the urban area, bordered by the urban perimeter. The preserved areas are outside this perimeter, in a fragile area susceptible to erosion, with a concentration of water springs. This boundary is based on geological and geotechnical maps.

When the participatory master plan was adopted in Bauru with 12 micro urban basins as a decentralized administrative model, Bauru took an enormous step towards sustainability [15]. The micro basin in the participatory master plan is able to address these two

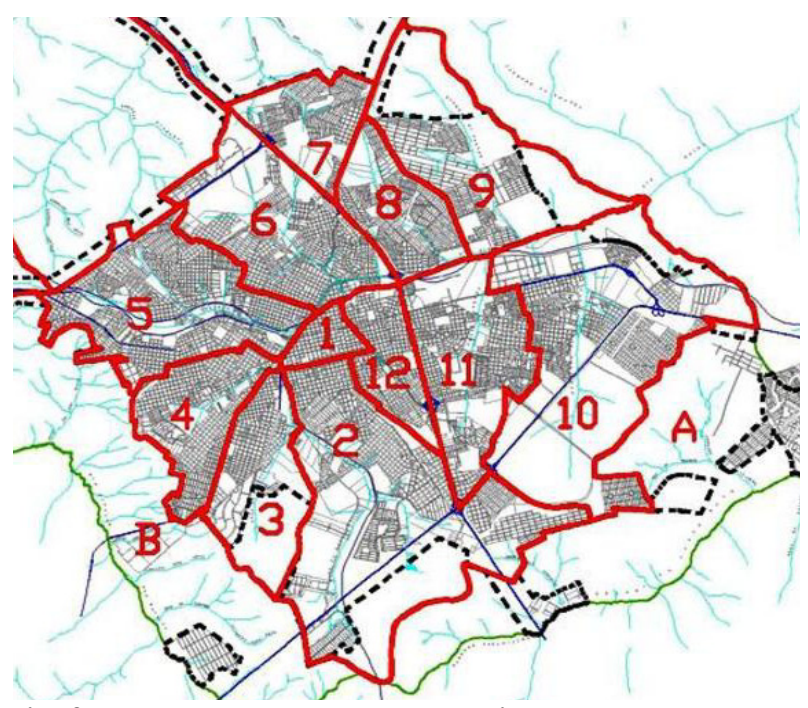

Fig. 3 The twelve planned sectors in Bauru based on the river basin and physical limits [15]. 
complex issues with land use soil and water management. The most important objective is to make this knowledge understandable to local users so that they adopt the micro basin as its own administrative territory.

In Bauru, the participatory master plan's initial stage count with the population was suggested by assemblies, council reunions, and community leaders by consultation with the municipal power. These popular efforts were a federal requirement.

According to the City Statute, the participatory master plan must be carried out with public participation. Some of the public meetings in Bauru were done by joining the micro basin's citizens. People made suggestions that were written down by the planning technicians and efforts were made to make the population understand the city's plans, including the river basin dynamics and the statute city guidelines.

\subsection{When the River Basin Became a Territory: A Case Study Research and Territory}

Defining administrative land division by micro basins allowed the citizens of Bauru to question about the territory and the identity of this new land division. Since this land was associated with water resources and environmental management, this was also a concern to some citizens.

When a public meeting took place to discuss the importance of the citizens of Bauru in the new participatory document, a new movement occurred in one of the basins, called Água Comprida. The citizens living in this river basin got to know each other, and by exchanging information, they learned how they impacted their neighbors. As an example, in Água Comprida, the inhabitants of the downstream realized that chemical products present in the river came from industrial enterprises located in the basin. This perception of the cause and effect led those inhabitants to adding sewage galleries and forest permanence movements, as well as to emphasizing the value of neighborhoods.

When the city administration came together with the inhabitants of the same micro basin to discuss the city's issues, a potential feeling of integration was generated among the people and a territory basin started to be integrated and recognized by a unique structure.

The territory is the basis of the work, residence, spiritual and material exchanges and life [16]. A territory is not only the result of natural and human systems but also the result of belonging to a land that belongs to us. The definition of a territory requires a region used by a given population.

In Água Comprida, a territorial movement has been formed against deforestation and the construction of walled settlements, a much discussed typology in the end of the 20th century. This typology maintains a gentrified city with segregation and a false idea of security [17]. In fact, a disconnected city with a small feeling of territory and identity is one of the causes of an unsafe city. Jacobs [18] contributes with thoughts about the urban city intimacy. In case the meetings were private, the city would not be useful.

Água Comprida and its forest have been studied by different researchers, at the same time as the planning incentives were carried out by the municipal power and the forest permanence movement.

The fragile ecosystem area and the large contribution of sandy soil to all river linear channels were known. The greatest pollution impacts were in the downstream area because of the absence of a sewage system and also due to the morphology of the basin.

The landforms are potentially eroding, despite of having a relatively low altimetry gap of approximately $140 \mathrm{~m}$ downstream from the head spigot and drain (Fig. 4). Inclined ramps with slopes favor the concentration of water flow in lines of preferential drainage. This fact, along with the sandstone substrate soil and a tropical climate with periods of alternating rain and drought, has increased erosion [19]. The erosive 


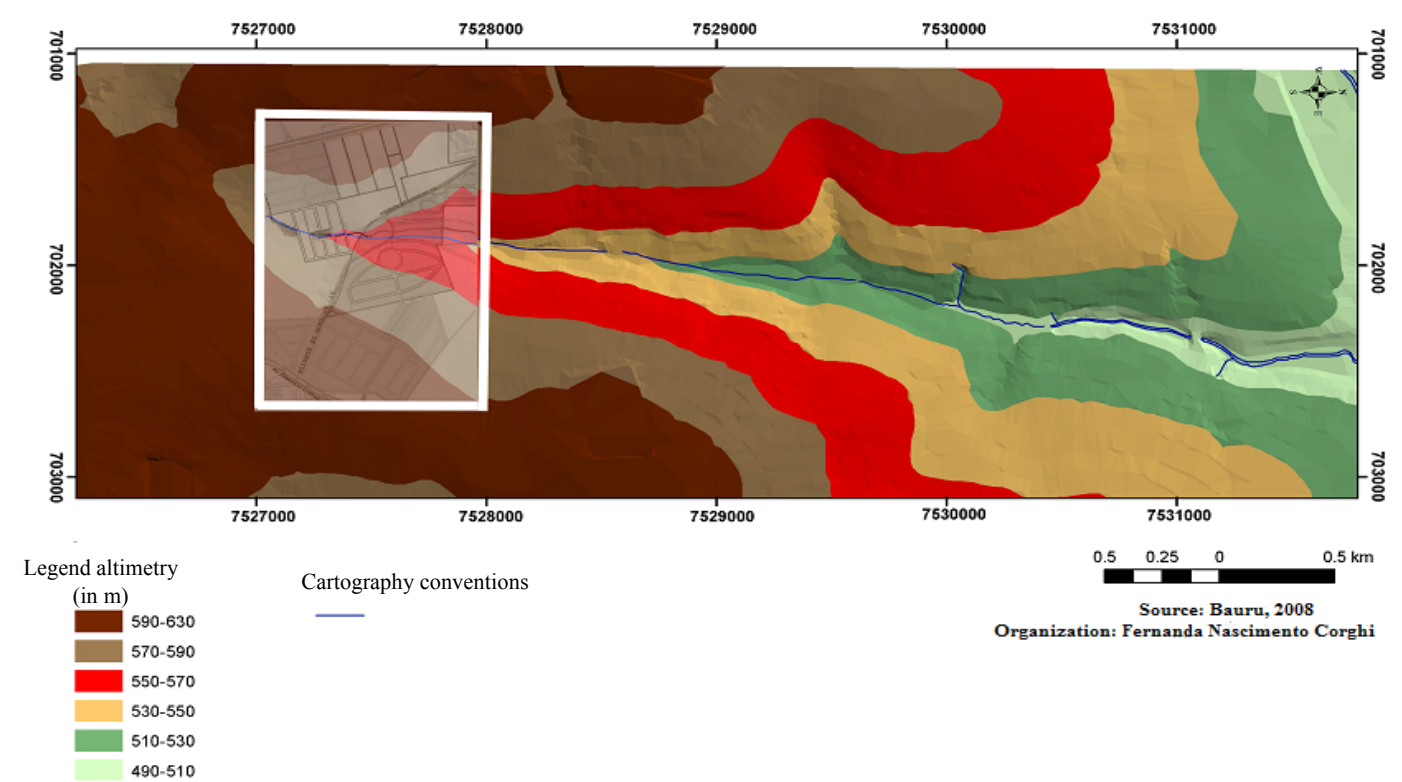

Fig. 4 Altimetric compartiment map of the Água Comprida River Basin.

Source: the value of neighborhood.

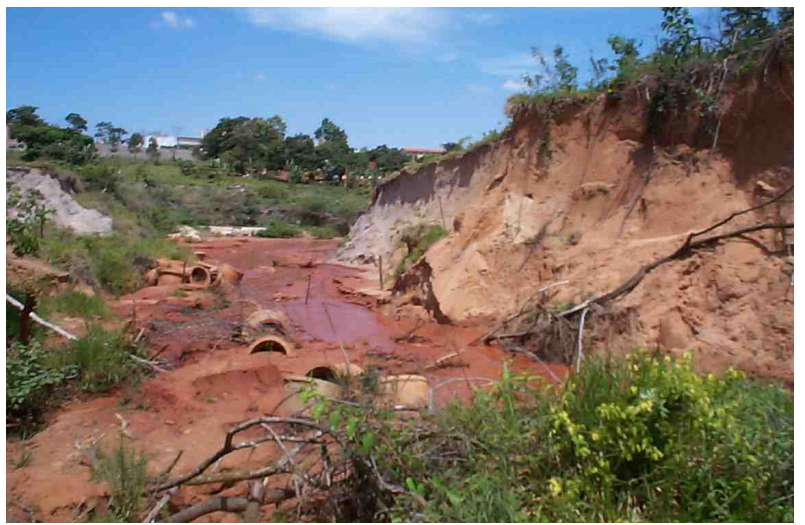

Fig. 5 Erosion episode due to mistakes in the drainage system and basin morphology.

episodes occurred in the spotlight area in the map (Figs. 4 and 5).

Research studies [20] helped, registered and provided technical support to the popular movement. Many research studies, including the study on river basin's susceptibility to erosion, were used. The population investigated new information and understood the permanence of the forest and the use of democratic spaces. This technique of support also helped citizens by exposing the population to the environmental council meeting, explaining City Statute tools, as well as environmental and human rights.
Information about environmental law and research was shared not only among inhabitants but also researchers, citizens and popular leadership without interference from government institutions. At the end of these discussions, it became impossible for the private enterprise to install its walled settlement in this rich place of natural capital.

The population had got what they wanted, i.e., a better quality of life in the basin territory. Now, the population really had the feeling of belonging to a land belonging to them. In fact, the citizens understood that the basin land behaved as an integrated area. This means that less natural capital results in a lower quality of life throughout the basin, especially at the end of the river, which is already an impacted area.

Researchers supported the movement by working with the citizens during all processes. The partnership culminated in international visibility of the movement against deforestation through a virtual petition.

This atypical movement can be related to the discussions for implementing the participatory Bauru master plan in the micro basin. In these meetings, popular leadership and researchers were in agreement 
and it was essential to combine singular movements of the same micro basin.

\section{A Dynamic Planner As a Sustainable Planning Way}

An educator-planner is a researcher that evolves with the cities' research and knowledge and gives technical support to the citizens [21]. This proposal was added for competence and a refined role was created especially to mediate a case study of Bauru and its citizens. A similar proposal was made [22] with different basins of São Paulo using study areas to reduce environmental agents' responsibility as to offer knowledge concerning management territory to their inhabitants and users.

This educator-planner set of abilities was mainly based on Souza's [21] studies that provided support to the citizens of Bauru. They made it possible for the community to understand the master plan, federal laws and the physical dynamics of the region. The educator-planner set also made it possible for the citizens to use democratic spaces to learn about the housing and environmental council and the supported petition with research data. This research study role allowed the citizens of Bauru to accomplish their goals during the subsequent stages of the master plan management and to reach the stages of implanting proposals.

To expand the proposal, Fig. 6 shows a scheme where an educator-planner acts as a bridge between the law and land technical knowledge, and the population can acquire this same knowledge, although in another way. This role is geared toward the continuity of planning stages, which means that a professional planner is a dynamic agent that allows the population to use this specific knowledge to increase their possibilities to fight for what they want and need. It means using the democratic spaces with specific knowledge by technical accessories to avoid environmental and social impacts in its territorial area, and recognizing the basin as a territory with the possibility of preventing impacts, if well understood and managed (Fig. 7).

To enact the subsequent stages of a participatory master plan, a real process demands "the role of executors of planning and decision-makers" [23]. In a country such as Brazil, in which the master plan has a history of not ensuring the poorest citizens environmental rights, the application of the master plan is already a challenge. It is possible to find in the literature [24] the main issues of Brazilian politics, such as a juridical matrix related to economic power, a restricted citizenship and a grey border between public and private spheres. In other words, monetary power and interests already regulate relations in Brazilian territory and it usually involves the use of public positions for private and undemocratic benefits.

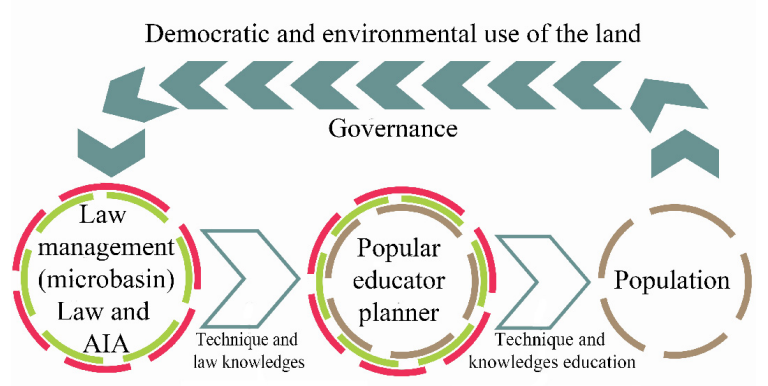

Fig. 6 The planner as a popular educator - a new role to architects and urbanists.

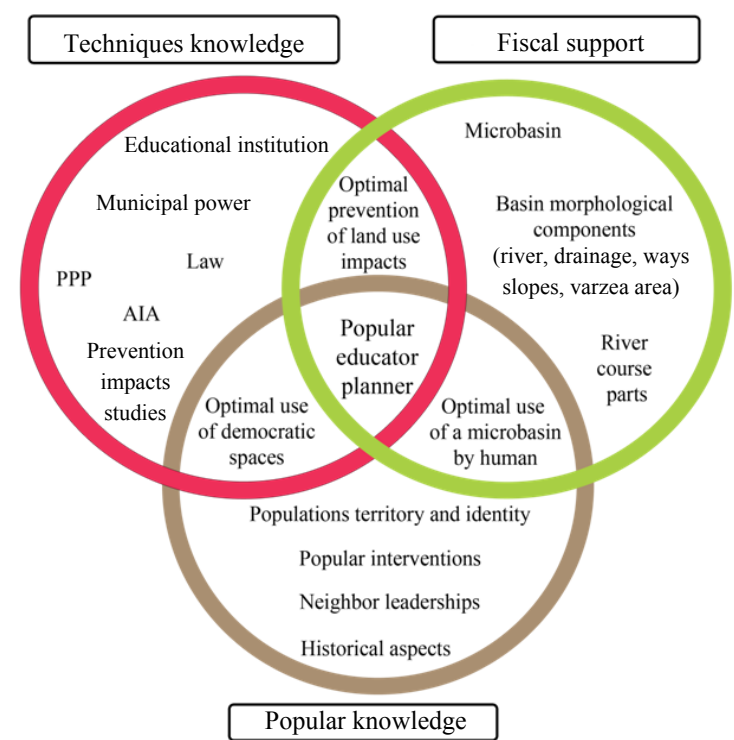

Fig. 7 The popular educator planner contributing to connect physical techniques and popular knowledge. 
After the Bauru participatory master plan was approved by the municipal power, the stages related to proposal application and management had not been completed, as the major power tried not to execute them as a means of allowing citizen urban reform and environmental rights to occur. In order to continue the process of planning discussions and to support citizens even after the end of public campaign once the master plan had been approved, the role of researchers was to provide continuous support to citizens in managing and applying the proposal stages (Fig. 8).

The challenge was to allow citizens to take part and to provide uninterrupted support at the first stage of the participatory master plan, without public support.

The proposal consisted of a continuous public process of planning through permanent support to citizens so they could discern and fight according to the master plan's instructions and make changes according to the project and their own needs.

\section{Repetition of Old Mistakes at Local and National Scales}

After the public national Brazilian consultation of citizens concerning the participatory master plan and questions related to enhance local governance, water management, social and environmental land use look feasible based on the newest federal laws concerning environmental and urban reform.

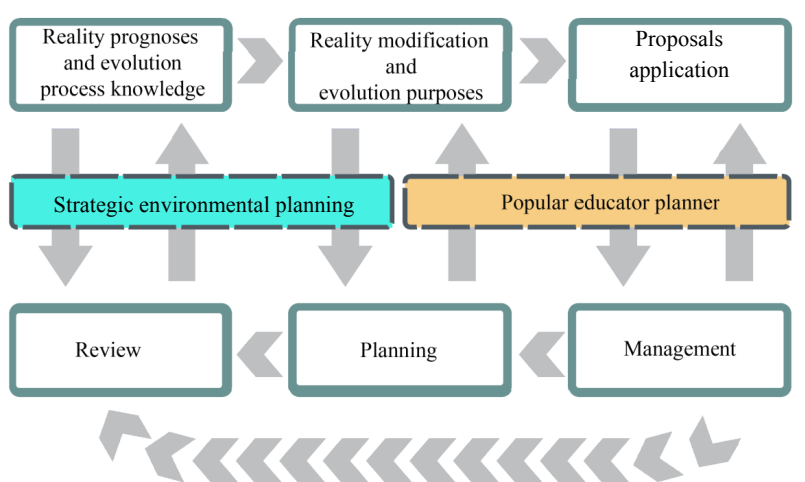

Fig. 8 The popular planner as a dynamic agent of the stages of management, proposal application and reality modification by extending the planning understanding to the citizens-modified from reference [23].
In Bauru, this plan was already under construction. Once the participatory master plan was approved by the Bauru municipal power in 2008, two years later, in accordance with the federal date, the public power was not concerned about notifying the citizens about their new territorial land division by the micro basin and what it means in terms of decentralized management.

A typical problem in Brazil is to create master plans just to comply with the law and then not to adopt them to really change people's life, especially the poorest ones [25]. The Bauru City plan, like others in the national territory, was not able to change lives without the stages of implementation and monitoring. According to the City Statute, democratic management can be formed through city councils, "participative budgets", assemblies and other public instances legalized by the master plan law.

However, no advanced democratic spaces are necessary to improve citizens' understanding about specific law and techniques. Even in such democratic spaces, a recurrent issue is the need for methods to support the population. When public techniques are discussed with citizens, they feel the need to defend their interests in front of the public [21].

In Brazil, the major issue of system urban policies is crediting the master plan with the power to change real life without implementing the plan or even knowing the effectiveness of its articles [25]. The efforts of the federal government have been reserved for the master plan and not for its results.

Despite these national considerations that arise in Bauru, further issues occur. In the final plenary of the Bauru participatory master plan, each article is voted on by the popular leadership. The drafting of a text after such a process is a legal procedure, although this allows many citizens to understand the master plan's instructions. Therefore, even this new Bauru land division plan by micro basin, though prominent from an environment and social standpoint, is not able to be adopted by citizens on the local scale because they 
lack understanding of the participatory master plan after its initial stages. The complete understanding of the Bauru master plan depends, at least, on the use of simple vocabulary with local brands and large scales drawn on the map.

Technical support to the citizens, even for the final master plan law, must be continued, such as in the initial stages, with public techniques clarifying the City Statute tools and master plan guidelines for the population. Despite praise for the Bauru master plan law, there were few efforts to keep citizens informed and able to manage their own administrative territory in Bauru as in other cities in Brazil.

A common issue in Brazil concerns the local population, which is the last to be clearly informed about major decisions, the priority master plan and other issues related to them and their territory. Its cause is the poor quality of data and the existence of delays between learning about a fact and communicating it to the citizens.

\section{Conclusions}

The Brazilian municipal power presents plenty of administrative mistakes even with the newest federal laws regarding environmental and urban reform rights. A specific city law left unimplemented - such as an urban reform agenda or laws concerning environmental rights - will not sway public opinion on such matters. This research studies a specific local governance reported in Bauru as to show a way to emphasize the effectiveness of popular intervention in public policies that seek to offer real results toward democratic and environmental rights.

The adoption of a micro basin has been shown to be the optimal territory scale to increase local governance and impact prevention, especially when inhabitants, users, researchers and public technicians are connected with a continuous process of planning and urban management.

In fact, the participatory stimulation is concentrated in the preliminary stages of the master plan law project, and cannot culminate in a planning process with the entire population being informed and joining the management, implementing and monitoring stages of municipal planning.

Once local power is strongly involved in the urban political process, the possibility for citizens to reach their own demands will increase more than when the master plan finally ends. This end represents, in most Brazilian cases, the beginning of the illusion of its implementation by the municipal power [25].

Participation can emphasize a process of urban planning and management by means of using a participatory master plan. The possibility to lead with a little river basin integrated with this own social capital makes it possible to connect between local interests according to concerns about climate and prevention impacts in a same micro basin.

The effective social and environmental use of land, which is the Brazilian urban law principium (Articles 182 and 183 of the constitution), needs to be integrated with an insurance of the public participation process and a rational use of the resources to ensure its availability to the next generations, as stated in Article 225 of the Brazilian Constitution. This solution means that well informed and critical citizens with supportive techniques have more autonomy and discernment when considering political decisions that affect the environment in which they live, as shown in the case study reported in this article.

\section{References}

[1] Batley, R. 1998. "Nuevas Direcciones en Politica y Gestion Urbana (New Directions in Politics and Urban Management)." In La Ciudad en el Siglo XXI: Experiencias Exitosas en Gestión del Desarrollo Urbano en el America Latina (The City in the 21st Century: Successful Experiences in Urban Development Management in Latin America), edited by Rojas, E., and Daughters, R. Barcelona: Banco de Desarrollo Interamericano (Inter-American Development Bank). (in Portuguese)

[2] Rolnik, R. 2011. "Democracy on the Edge: Limits and Possibilities in the Implementation of an Urban Reform Agenda in Brazil." International Journal of Urban and 
Regional Research 35 (2): 239-55.

[3] Harvey, D. 1989. The Condition of Postmodernity: An Inquiry into the Origins of Cultural Change. Oxford: Willey-Blackwell.

[4] IAIA (International Association for Impact Assessment). 2006. Public Participation International Best Practice Principles. Fargo: International Association for Impact Assessment. Accessed October 5, 2010. http://www.iaia.org/publicdocuments/special-publications /SP4\%20web.pdf?AspxAutoDetectCookieSupport=1.

[5] Taddei, R. 2011. "Watered-Down Democratization: Modernization versus Social Participation in Water Management in Northeast Brazil." Agriculture and Human Values 28: 109-21.

[6] Botelho, R. G. M. 1980. "Environmental Planning in Microbasin.” In Geomorfologia (Geomorfology), edited by Christofoletti, A. 2nd ed.. São Paulo: Edgard Blücher. (in Portuguese)

[7] Tucci, C. E. M. 2001. "Gerenciamento da Drenagem Urbana (Elements to Urban Drainage Control)." RBRH-Revista Brasileira de Recursos Hidricos (Brazilian Review of Hydric Resources) 7 (1): 5-27. (in Portuguese)

[8] AEM (Millennium Ecosystem Assessment). 2005. Millennium Ecosystem Assessment. Ecosystems and Human Well-Being: Scenarios-Findings of the Scenarios Working Group. Washington, D.C.: Island Press.

[9] Farr, D. 2008. Sustainable Urbanism: Urban Design with Nature. Hoboke: Wiley.

[10] Bronx. 2014. "Bronx River Alliance." Bronx. Accessed May 24, 2014. http://www.bronxriver.org/index.php? $\mathrm{pg}=$ content $\& \mathrm{p}=$ bronxriveresources.

[11] Ide, D. M., Silva, R. A., Corghi, F. N., and Giacheti, H. L. 2010. "Erosion Process Caused by an Urban Setting in Brazil." Presented at Sixth International Congress on Environmental Geotechnics, Nova Delhi, India.

[12] Alves, J. X. S. 2001. "Voçorocas do Poder Público: Na lei, Forma e Gestão Urbana da Cidade Sem Limites (Erosions of the Public Power: In Law, Form and Urban Management in the without Limits City)." $\mathrm{PhD}$ thesis, University of São Paulo. (in Portuguese)

[13] Filho, G. S. A. 2000. "Diagnóstico De processos Erosivos Lineares Associados a Eventos Pluviosos no Município de Bauru, SP (Diagnosis of Linear Erosion Processes Associated with Rain Water in Bauru, State of São Paulo)." Master dissertation, State University of Campinas. (in Portuguese)

[14] Losnak, C. J. 2004. Polifonia Urbana: Imagens $e$ Representações (Urban Poliphony: Images and Representations). Bauru: EDUSC (Sacred Heart University Press). (in Portuguese)
[15] Bauru Municipal Power. 2008. Plano Diretor Participativo (Bauru Master Plan). Bauru: Bauru Municipal Power. Accessed October 5, 2010. http:/hotsite.bauru.sp.gov.br/planodiretor/. (in Portuguese)

[16] Santos, M. 2001. Por Uma Outra Globalização: Do Pensamento Único à Consciência Universal (For Another Globalization: From the Single Thought to the Universal Consciousness). Rio de Janeiro: Record. (in Portuguese)

[17] Caldeira, T. P. R. 2000. City of Walls: Crime, Segregation and Citizenship in São Paulo. Berkeley: University of California Press.

[18] Jacobs, J. 2009. The Death and Life of Great American Cities. São Paulo: WMF Martins Fontes.

[19] Corghi, F. N. 2008. "Urbanização e Segregação Sócioespacial em Bauru (SP): Um Estudo de Caso Sobre a Bacia Hidrográfica do Córrego da Água Comprida (Urbanization and Socio-spacial Segregation in Bauru (SP): A Case Study of the Hydrographic Basin of the Água Comprida Stream).” Master thesis, State University of Campinas. (in Portuguese)

[20] Santos, J. A. 2008. "Cidade e Natureza: Relações Entre a Produção do Espaço Urbano, a Degradação Ambiental e os Movimentos Sociais em Bauru-SP (City and Nature: Relations among the Urban Space Production, the Environmental Degradation and the Social Movements in Bauru-SP)." PhD thesis, State University of Campinas.

[21] Souza, M. L. 2006. A Prisão e Ágora: Reflexões em Torno da Democratização do Planejamento e da Gestão das Cidades (The Prison and the Agora: Thoughts Concerning Democratization of Planning and Management of Cities. Rio de Janeiro: Bertrand Brazil.

[22] Spaolonzi, A. E., Rutkowski, E. W., Corghi, F. N., Cortijo, M., and Dalbelo, T. S. 2011. "Bacia Ambiental Como Matriz Pedagógica: uma Experiência Formativa (Environmental Basin as a Pedagogic Matrix: A Formative Experience)." Presented at VIII Congreso de Educación Ambiental para el Desarollo Sostenible, Havana (VIII Congress of Environmental Education for the Sustainable Development). (in Portuguese)

[23] Santos, R. F. 2004. Planejamento Ambiental: Teoria e Prática (Environmental Planning: Theory and Practice). São Paulo: Oficina de Textos (The Text Workshop Press). (in Portuguese)

[24] Maricato, E. 2008. Brasil, Cidades: Alternativas Para a Crise Urbana (Brazil, Cities: Alternatives to the Urban Crisis). Petrópolis: Vozes.

[25] Villaça, F. 2005. "A Ilusão do Plano Diretor (The Master Plan Illusion).” PhD thesis, University of São Paulo. (in Portuguese) 